competitive ability in the food market of Ukraine. The following are distinguished as main directions for an effective promoting of bread on the basis of wheat whole grain in the food market of Ukraine: flexible pricing policy, an active role of the marketing in the product promoting, line extension, and also implementation of the package plan concerning the development of the consumer itself in the nutrition problem, in the problems of a healthy lifestyle, that results in the stimulation of the consumer to purchase this productthe product of healthful purpose.

Keywords: SWOT-analysis, based on whole grain wheat, the consumer market, marketing.

\title{
REFERENCES
}

1. Voronina V.M., Kokarev A.I SWOT analysis as a modern research tool for crisis management of an enterprise// Monthly analytical magazine "Mergers and Acquisitions", 2007. - №3 (49). - P. 23-26

2. Yegorov B.V., Mardar M. R. Model of formation of consumer properties of foodstuff functional orientation/ B.V.Yegorov, M. R. Mardar //Grain Products and Mixed Fodder's . - 2009. -№3. - P.11-14

3. Benedetto, C.A. Identifying the key success factors in new product launch / C.A. Benedetto // J. Prod. Innov. Manag. 2005. - №16(6). P. 530-544.

4. Pastukhov V.V. Use of SWOT analysis in the selection process of the global strategy of the enterprise: a Practical on-the expedient. OJSC Donetsk Trading House "Donbass"2000. - 74 p .

5. Mardar M. R. The importance of marketing research in the development of new products / M. R. Mardar // Expert in food products. 2013. - № 3. - P. 63-68

6. Yegorov B.V. Scientific basis for the formation of consumer properties of new grain products: monograph /B.V.Yegorov, M. R. Mardar - Odessa: TES, 2013. - 388 p.

7. Mardar M. R. Grain products on the basis of a whole grain - are the products of health improving nutrition/ M. R. Mardar // Food processing industry magazine. - 2013. - № 2. - P.. 31-34

Поступила 20.06.2014

Адрес для переписки: ул. Канатная, 112, г. Одесса, 65039

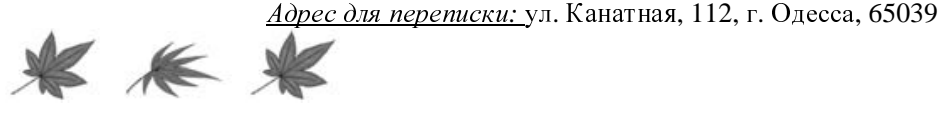

У ДК [636.085.55-021.632:577.15]:636.4

О.Й. КАРУНСЬКИЙ, д-р с.-г. наук, професор, Одеський державний аграрний університет

В.С. БРАЖЕНКО, канд. техН. Наук, доцент, Я.О. ВЕЛЕСИК, магістр

Одеська начіональна академія харчових технологій

\section{ТЕХНОЛОГІЯ ВИРОБНИЧТВА КОМБІКОРМОВОЇ ПРОДУКЦІЇ ДЛЯ СВИНЕЙ, ЗБАГАЧЕНОЇ ЛІЗОЦИМОМ}

У статті наведено характеристику імунної системи організму людини та функиіональне призначення ферментів. На сьогодні одним із головних напрямків підвищення імунної системи людини є виробниџтво безпечної продукції рослинного та тваринного походження. Отримання високоякісної продукції тваринного походження залежить від генетичних особливостей порід свиней, умов утримання, програми відгодівлі на всіх етапах вирощування із забезпеченням високоефективними кормами, на якісні властивості яких впливають впровадження інноваџійних технологій виробниџтва, рівень наукових розробок рецептів комбікормової продукиї з науково обтрунтованим застосуванням ферментних препаратів. Визначено основну біологічну дію кормових ферментів. Теоретично обтрунтовано застосування ферментного препарату лізоциму у складi комбікормової продукиії при годівлі тварин. Встановлено, щңо введення ферментного препарату лізоциму до складу комбікормів сприяє підвищенню їхньої продуктивної дії при годівлі тварин.

Теоретично та експериментально досліджено ефективність введення ферментного препарату лізоциму, покритого оболонкою із желатину, до складу комбікормової продукиї̈. Визначено біологічну ефективність комбікормової продукції, збагаченої лізоцимом, та ефективне використання ферментного препарату лізоциму в раціонах годівлі шурів.

Розраховано склад рецепту комбікорму із застосуванням програми «КормОптима» та визначено оптимальний вміст лізоциму відповідно до норм годівлі та показників поживної цінності готової продукиї̈ для свиней.

Розроблено технологію введення препарату лізочиму та отримано дослідну партію комбікорму для годівлі тварин. Проведено науково-господарські досліди для вивчення ефективності використання ферментного препарату лізочиму в раиіонах годівлі свиней

Визначено зоотехнічну ефективність комбікормової продукцї, збагаченої лізочимом, покритим оболонкою із желатину, виробленої за розробленою технологією, для свиней. Встановлено, щуо застосування препарату лізоциму при вирощуванні молодняку свиней дозволяє отримати більшу продуктивність при менших витратах кормів на одиницю продукцї̈.

Ключові слова: комбікормова продукиія, препарат лізоциму, технологія введення ферментного препарату, продуктивна дія.

Здоровий спосіб життя людини досягається за допомогою функціонування всіх систем організму, зокрема імунної системи. Структурна та функціональна праця імунної системи організму людини залежать від факторів неспецифічного характеру, екологічного стану навколишнього середовища, віку і функціональної стійкості нервової системи, якості продукції рослинного та тваринного походження. Усі системи організму людини, тварин і рослин наділені властивостями самозахисту від мікроорганізмів. Наприклад, у сльозовій рідині, слині, крові та лімфі $\epsilon$ лізоцим (речовина білкової природи), а чиста шкіра людини виділяє лізоцимоподібну речовину, яка згубно діє на хвороботворні мікроби. Підвищення імунної системи організму людини можливе при забезпеченні високоякісною продукцією рослинного та тваринного походження. Так, отримання високоякісної свинини залежить від генетичних особливостей порід 
свиней, умов утримання, програми відгодівлі на всіх етапах вирощування із забезпеченням високоефективними кормами, на якісні властивості яких впливають впровадження інноваційних технологій виробництва, рівень наукових розробок рецептів комбікормової продукції з науково обгрунтованим застосуванням ферментних препаратів, що дозволить підвищити продуктивну дію поживних речовин. Проблеми підвищення продуктивної дії та показників поживної цінності комбікормової продукції відповідно до програми відгодівлі свиней на всіх етапах вирощування залишаються актуальними.

Метою роботи є підвищення продуктивної дії комбікормової продукції, збагаченої ферментним препаратом лізоцимом. Для досягнення мети поставлено такі завдання:

- аналіз властивостей ферментного препарату лізоциму;

- визначення біологічної ефективності комбікормової продукції, збагаченої лізоцимом;

- розрахунок рецепту комбікормової продукції, збагаченої ферментним препаратом лізоциму;

- розробка схеми технологічного процесу введення ферментного препарату лізоциму до складу комбікормової продукції;

- визначення зоотехнічної ефективності комбікормової продукції, збагаченої лізоцимом;

- визначення економічної ефективності вирощування молодняку свиней з 4-х до 7-ми місяців при відгодівлі комбікормовою продукцією, збагаченою ферментним препаратом лізоциму.

Відомо, що ферменти - це білкові каталізатори, які контролюють у живому організмі всі хімічні реакції, в тому числі й процеси травлення, вступаючи на певний час у контакт із субстратом, створюють нестійку сполуку фермент-субстрат. Нестійка сполука розпадається на продукти реакції та вільний фермент. Дефіциту ферментної активності можна запобігти, додавши кормові ферментні препарати. За аналізом літературних даних основна біологічна дія кормових ферментів полягає в $[1,2]$ :

- поліпшенні засвоювання білків та вуглеводів комбікорму за рахунок руйнування клітинних оболонок;

- підвищенні активності власних травних ферментів та процесів всмоктування;

- поліпшенні мікробіологічного середовища в кишках внаслідок зниження густини;

- запобіганні дефіциту травних ферментів на ранніх стадіях розвитку та при стресі.

Висока специфічність ферментів обумовлена конформаційною і електростатичною комплементарністю між молекулами субстрату та ферменту й унікальною структурою активного центру ферменту, що забезпечують «впізнавання», високу спорідненість і вибірковість протікання однієї якої-небудь реакції з тисячі інших хімічних реакцій, які здійснюються одночасно в живих клітинах $[3,4]$.

Залежно від механізму дії розрізняють ферменти з відносною (або груповий) специфічністю і абсолютною специфічністю. Так, для дії деяких гідролітичних ферментів найбільше значення має тип хімічного зв'язку в молекулі субстрату. Так, гідроліти- чний фермент - лізоцим вибірково розщеплює полісахариди клітинної оболонки бактерій. Він належить до невеликих за розмірами білків, відносно термостабільний (витримує температуру пастеризації) і виробляється багатьма органами і тканинами організму людини, тварин і навіть рослин. Розщеплюючи полісахариди клітинної оболонки бактерій, лізоцим здійснює бактеріолітичну дію, знищуючи бактерії, особливо роду Clostridium. Але це не єдина і навіть не головна властивість лізоциму. Він має імуномодулюючу дію, активуючи систему природженого і набутого імунітету. Відомі дані про його антидисбіотичну дію, що дозволяє віднести лізоцим до пребіотиків $[3,4]$. Встановлено, що застосування препаратів лізоциму впливає на збільшення приросту живої маси тварин. Близько однієї третини органічної речовини, що надходить 3 кормом, зазвичай не перетравлюється тваринами. Зниження цих втрат лише на $2 \ldots .3 \%$ дозволяє отримати сотні тонн додаткової продукції $[1,2,5]$. Однією з можливостей вирішення цього завдання є додавання в корми для тварин ферментних препаратів лізоциму, але особливість їхнього застосування полягає в тому, що висока ефективна дія лізоциму досягається за рахунок певної масової частки у складі кормів відповідно до призначення. Тому необхідно визначити оптимальний вміст препарату лізоциму у складі кормів для підвищення їхньої продуктивної дії при відгодівлі свиней.

Експериментальні дослідження для вивчення біологічної ефективності комбікормової продукції, збагаченої лізоцимом, та ефективного використання ферментного препарату лізоциму в раціонах годівлі щурів проводились на кафедрі Інституту стоматології. В роботі був використаний ферментний препарат лізоциму, покритий оболонкою із желатину, який додавали в корм щурам по 250 мг продукту кожній особині. Дослідження проводили на двох групах білих щурів, кожна з яких складалась із 6-ти особин (самці віком 2,5 місяці). Першій групі щурів (контрольній) згодовували лише комбікорм ПК-120-4, а в раціон годівлі другої групи вводили комбікорм + лізоцим у желатині протягом 10 днів. Динаміка росту середньої маси тіла щурів вказує на те, що за однаковий період годівлі та група щурів, яка споживала комбікорм, до складу якого додавали ферментний препарат лізоциму, покритого оболонкою із желатину, швидше набирає масу тіла (рис. 1). Інтенсивність росту особин у контрольній та дослідній групах визначено за оцінками абсолютного та відносного приростів маси тіла щурів (рис. 2, 3).

3 метою подальшого вивчення ефективності введення ферментного препарату лізоциму до складу комбікормів виконано розрахунки складу рецепту комбікорму з визначення оптимального вмісту лізоциму відповідно до норм годівлі та показників поживної цінності готової продукції для свиней. Розрахунок складу рецепту та оптимізацію показників якості виконано із застосуванням програми «КормОптима» (табл. 1).

Розроблено структурну схему технології введення препарату лізоциму, покритого оболонкою із желатину, до складу комбікормової продукції (рис.4). 
За складом рецепту та розробленою технологією введення препарату лізоциму отримано партію комбікорму для годівлі тварин. Науково-господарські досліди для вивчення зоотехнічної ефективності збагачення комбікормів ферментним препаратом лізоцимом проводилися на державному підприємстві «УЧГОСП ім. А.В. Трофімова» Овідіопольського району Одеської області протягом 2013 р. Для проведення досліду зоотехнічної ефективності комбікормів сформовано три групи поросят по 12 голів у кожній із тварин - аналогів. Дослідний період тривав від 4 до 7-місячного віку. Тварин піддослідних груп годували раціонами згідно з прийнятою схемою проведення досліду. У порівняльний період усі групи отримували однаковий комбікорм.

В основний період досліду різниця у годівлі полягала в тому, що в раціони II і III дослідних груп вводили відповідно $1 \%$ і 2\% пре-преміксу лізоциму.

Тварин усіх груп годували згідно з деталізованими нормами відгодівлі.

У результаті введення добавки лізоциму до складу раціонів приріст живої маси у II та III дослідних групах був більшим за контроль на $4,7 \%$ та 5,3\% відповідно (табл. 2).

Тварини дослідних груп відрізнялися вищою інтенсивністю росту, що обумовило їх вищу продуктивність і менші витрати корму на 1 кг приросту,

Таблиця 1

Склад рецепту повнораціонного комбікорму для відгодівлі дослідних груп свиней живою масою 40...70 кг

\begin{tabular}{||l||c||c||}
\hline \multirow{2}{*}{ Компоненти } & \multicolumn{2}{|c|}{ Вміст } \\
\cline { 2 - 3 } & $\begin{array}{c}\text { масових } \\
\text { часток } \\
\text { компоне- } \\
\text { нтів, \% }\end{array}$ & $\begin{array}{c}\text { масових } \\
\text { часток } \\
\text { сирого } \\
\text { протеїну, \% }\end{array}$ \\
\hline \hline Ячмінь & 48,4 & 39,0 \\
\hline \hline Овес & 18,7 & 14,3 \\
\hline \hline Пшениця & 12,8 & 11,5 \\
\hline \hline Горох екструдований & 2,7 & 4,2 \\
\hline \hline Висівки пшеничні & 10,0 & 10,7 \\
\hline \hline Рибна мука & 5,3 & 19,9 \\
\hline \hline Сіль кухонна & 0,5 & 0 \\
\hline \hline Трикальційфосфат & 0,6 & 0 \\
\hline \hline Премікс КДС-1 & 1 & 0 \\
\hline \hline $\begin{array}{l}\text { ФП лізоцим у складі } \\
\text { преміксу КДС-1 }\end{array}$ & 0,28 & 0 \\
\hline \hline Разом & 100 & \\
\hline \hline
\end{tabular}

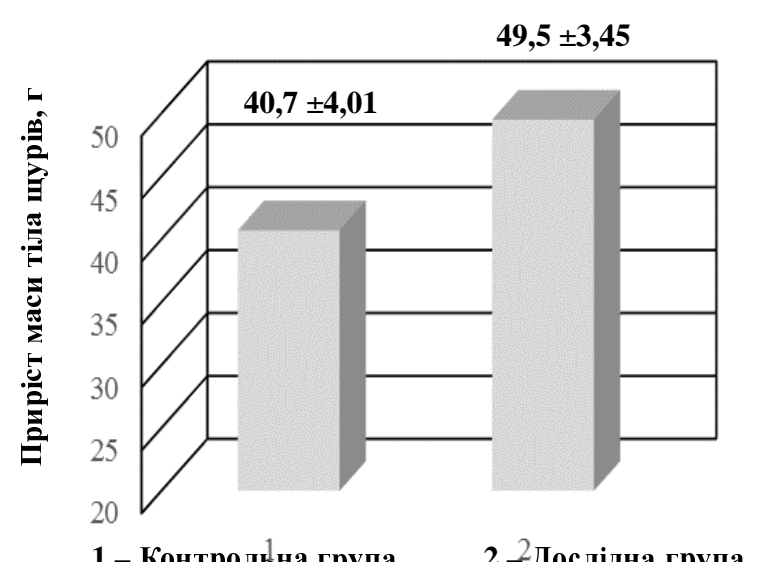

Рис. 2 - Абсолютний приріст маси тіла щирів

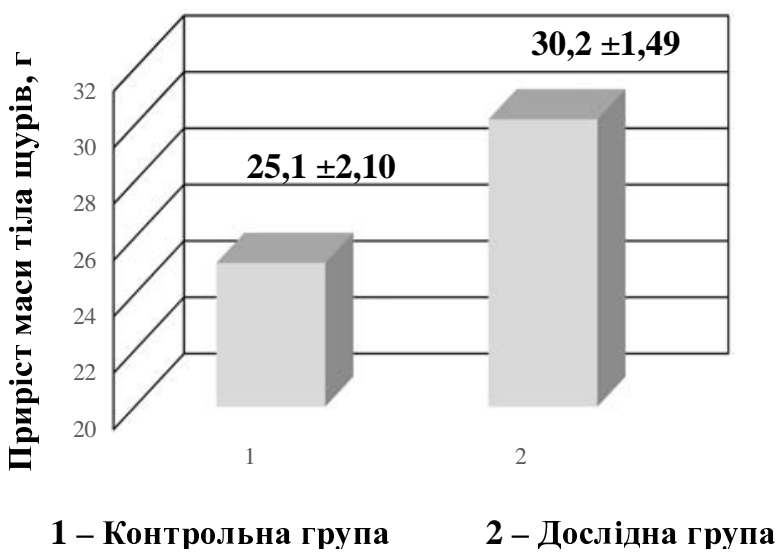

Рис. 3 - Відносний приріст маси тіла шурів

порівняно з контрольною групою. Вища продуктивність тварин дослідних груп зумовила нижчі витрати корму на 1 кг приросту (рис. 5, 6).

Тварини II дослідної групи досягали живої маси 100 кг на 6,4 доби раніше ( $<<0,001)$, а III дослідної групи на 7,2 доби раніше (p<0,001), ніж аналоги I групи. Згідно з отриманими даними індексу рівномі- 
Динаміка абсолютних та середньодобових приростів свиней

Таблиия 2 за період вирочування від 4 до 7-місячного віку $(n=12)$

\begin{tabular}{|c|c|c|c|c|}
\hline \multirow[t]{2}{*}{ Група } & \multirow[t]{2}{*}{ Показники } & \multicolumn{3}{|c|}{ Вік тварин, місяць } \\
\hline & & 5 & 6 & 7 \\
\hline \multirow[t]{2}{*}{ I (контрольна) } & Абсолютний приріст, кг & $18,68 \pm 0,656$ & $21,68 \pm 0,191$ & $19,72 \pm 0,303$ \\
\hline & Середньодобовий приріст, г & $602,7 \pm 21,25$ & $722,8 \pm 6,35$ & $679,9 \pm 10,44$ \\
\hline \multirow[t]{4}{*}{ II (дослідна) } & \% до контролю & 102,5 & 104,6 & 104,7 \\
\hline & Абсолютний приріст, кг & $20,25 \pm 0,389$ & $\begin{array}{c}23,93 \pm 0,568 \\
* *\end{array}$ & $\begin{array}{c}20,78 \pm 0,363 \\
*\end{array}$ \\
\hline & Середньодобовий приріст, г & $653,4 \pm 12,55$ & $\begin{array}{c}797,8 \pm 18,93 \\
* *\end{array}$ & $\begin{array}{c}716,6 \pm 12,52 \\
*\end{array}$ \\
\hline & \% до контролю & 108,4 & 110,4 & 105,4 \\
\hline \multirow[t]{4}{*}{ III (дослідна) } & \% до контролю & 103,2 & 105,3 & 105,3 \\
\hline & Абсолютний приріст, кг & $20,0 \pm 0,392$ & $\begin{array}{c}24,14 \pm 0,673 \\
* *\end{array}$ & $\begin{array}{c}20,73 \pm 0,140 \\
* *\end{array}$ \\
\hline & Середньодобовий приріст, г & 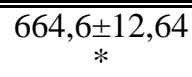 & $\begin{array}{c}804,7 \pm 22,43 \\
* *\end{array}$ & $\begin{array}{c}714,8 \pm 4,84 \\
* *\end{array}$ \\
\hline & \% до контролю & 110,3 & 111,3 & 105,1 \\
\hline
\end{tabular}

Примітка: * р<0,05; ** р<0,01; *** р<0,001, порівняно з контрольною групою.

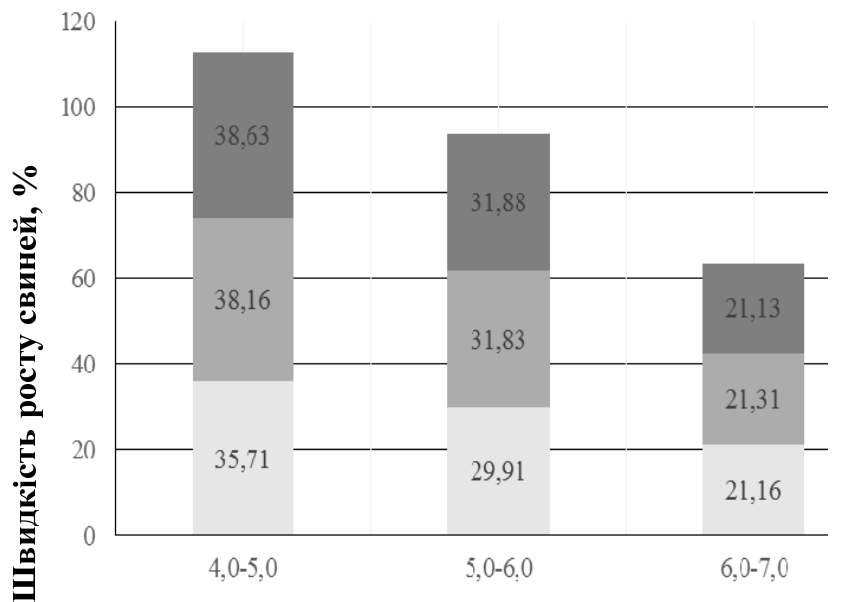

Вік тварин, місяців

Рис. 5 - Відносна швидкість росту свиней

рності в дослідних групах тварини досягали живої маси 100 кг більш рівномірно, ніж у контрольній. В цілому отримана продуктивність, закономірності росту та відгодівельні якості піддослідних тварин свідчать про позитивну дію лізоциму на обмінні процеси організму молодняку свиней (рис. 7).

Витрати кормів на отримання 1 кг живої маси свиней в дослідних групах складали на 7,5\% та 7,8 \% менше, ніж у контрольній (табл. 3).

Економічну ефективність визначали на основі фактичних витрат кормів на 1 ц приросту. Інші господарські витрати (на зарплату, амортизацію) протягом досліду за 2013 рік були однакові для всіх груп.

Економічна ефективність вирощування молодняку показала, що раціони різного складу суттєво вплинули на формування основних витрат та створення чистого прибутку в розрахунку на 1 голову. Найменші витрати були у тварин III дослідної групи873,9 грн, або на 67,06 грн менше, ніж у тварин I контрольної групи.

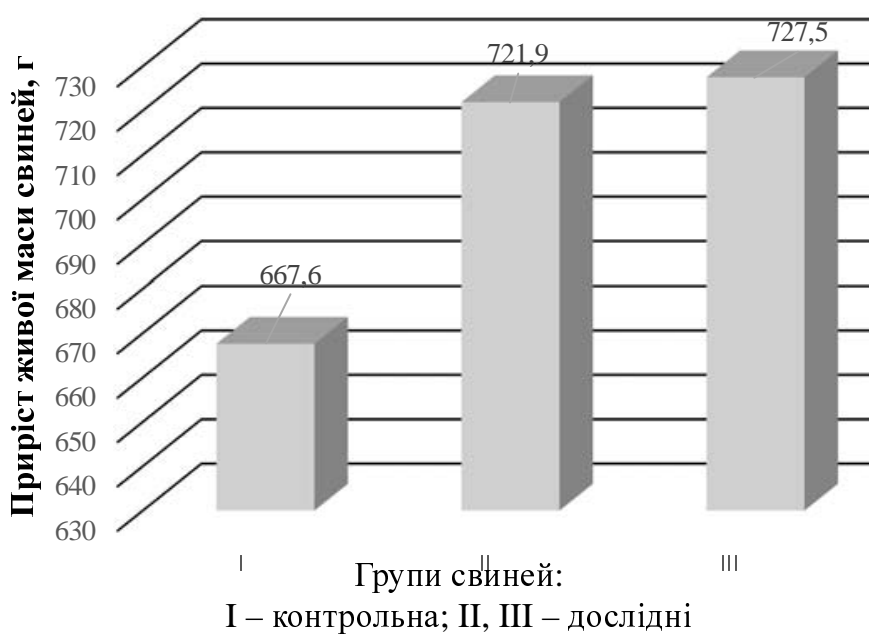

Рис. 6-Середньодобовий приріст живої маси свиней

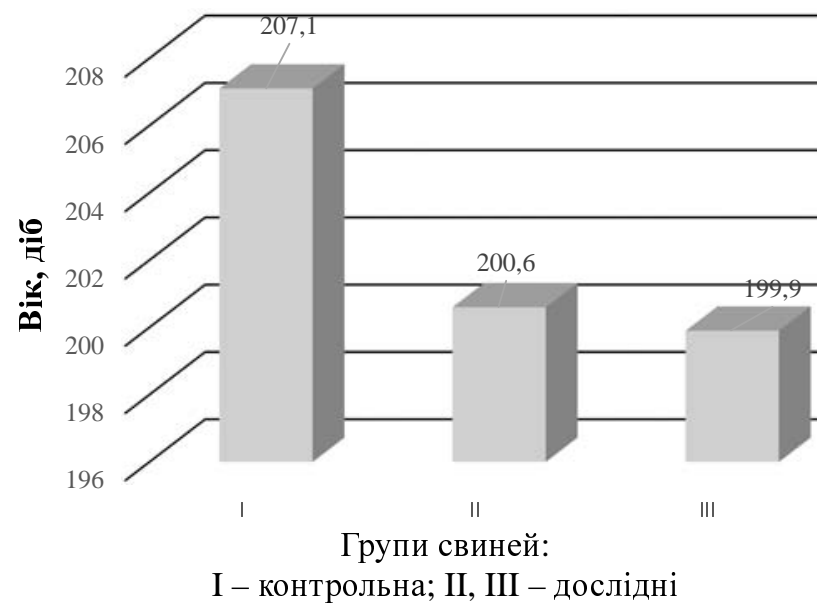

Рис. 7 - Вік досягнення жсивої маси свиней 100 кг 
Витрати корму на 1 кг приросту живої маси при вирощуванні від 4 до 7-місячного віку

\begin{tabular}{|c|c|c|c|}
\hline Погазник & \multicolumn{3}{|c|}{ Групи тварин } \\
\hline Витрати на 1 кг приросту: & I (контрольна) & II (дослідна) & III (дослідна) \\
\hline сухої речовини, кг & 3,688 & 3,424 & 3,405 \\
\hline кормових одиниць & 4,72 & 4,37 & 4,33 \\
\hline обмінної енергії, МДж & 52,2 & 48,9 & 49,2 \\
\hline сирого протеїну, г & 549,9 & 549,0 & 542,9 \\
\hline перетравного протеїну, г & 464,4 & 426,5 & 419,7 \\
\hline сирого жиру, г & 127,8 & 136,0 & 152,0 \\
\hline
\end{tabular}

Таблиця 4

Економічна ефективність вирощування молодняку свиней від 4 до 7-місячного віку

\begin{tabular}{|c|c|c|c|}
\hline \multirow{2}{*}{ Показники } & \multicolumn{3}{|c|}{ Групи тварин } \\
\hline & I (контрольна) & II (дослідна) & III (дослідна) \\
\hline Кількість голів у групі & 12 & 12 & 12 \\
\hline Приріст на 1 голову за період & 60,08 & 64,97 & 65,47 \\
\hline Витрати кормів на 1 кг приросту, корм. од. & 4,72 & 4,37 & 4,33 \\
\hline Витрати натурального корму, кг & 263,71 & 274,82 & 285,31 \\
\hline Витрати кормів на 1 голову, корм. од. & 283,34 & 283,79 & 283,77 \\
\hline Усього витрат на вирощування однієї голови, грн & 940,96 & 897,39 & 873,90 \\
\hline \multicolumn{4}{|l|}{ в тому числі: } \\
\hline корм, грн & 922,99 & 879,42 & 855,93 \\
\hline зарплата, грн & 14,47 & 14,47 & 14,47 \\
\hline амортизація, грн & 3,50 & 3,50 & 3,50 \\
\hline Виручка від реалізації приросту однієї голови, грн & 1398,27 & 14993,26 & 1530,20 \\
\hline \multicolumn{4}{|l|}{ Прибуток від реалізації, грн: } \\
\hline о одержаного приросту однієї тварини & 457,31 & 595,87 & 656,30 \\
\hline групи тварин & 5487,72 & 7150,44 & 7875,60 \\
\hline Рівень рентабельності, \% & 48,6 & 66,4 & 75,1 \\
\hline
\end{tabular}

Від реалізації однієї голови з І групи одержано 457,31; II - 595,87 i III - 656,30 грн чистого прибутку.

Чистий прибуток від вирощування тварин у контрольній групі становив 5487,72 грн при рівні рентабельності виробництва - 48,6\%. У ІІ дослідній групі чистий прибуток становив 7150,44 грн при рівні рентабельності виробництва - 66,4\%. У III дослідній групі чистий прибуток і рентабельність склали відповідно 7875,60 грн і 75,1\% (табл. 4).

\section{Висновки}

1. Теоретично й експериментально обгрунтовано масову частку ферментного препарату лізоциму у складі комбікормової продукції для свиней.
2. Розроблено схему технології введення ферментного препарату лізоциму, покритого оболонкою із желатину, до складу комбікормів.

3. Визначено зоотехнічну ефективність комбікормової продукції, збагаченої лізоцимом, покритим оболонкою із желатину, виробленої за розробленою технологією, для свиней. Встановлено, що застосування препарату лізоциму при вирощуванні молодняку свиней дозволяє отримати більшу продуктивність при менших витратах кормів на одиницю продукції.

4. Визначено, що найвищий рівень рентабельності при вирощуванні свиней від 4 до 7-місячного віку $(75,1 \%)$ одержали в III дослідній групі, де використовували комбікорм із додаванням 20 г/кг препарату лізоциму. 
1. Сгоров, Б.В. Технологія виробнищтва комбікормів [Текст]: підруч. для вищ. навч. закладів / Б.В. Сгоров. - Одеса.: Друкарський дім, 2011. - 448 с.

2. Егоров, Б.В. Опыт эксплуатации комбикормовых заводов IV поколения [Текст] / Б.В. Егоров, Н.В. Ворона // Зернові продукти і комбікорми. - 2011. - № 4. - С. 24 - 29.

3. Левицкий, А.П. Лизоцим вместо антибиотиков [Текст] / А.П. Левицикий. - Одеса.: КП ОГТ, 2005. - 74 c.

4. Сгоров, Б.В. Технологія виробниитва преміксів [Текст] : підручник / Б.В. Сгоров, О.І. Шаповаленко, А.В. Макаринська. - К.: Центр учбової літератури, 2007. - 288 с.

5. Шаповаленко, О.І. Шляхи розвитку виробництва комбікормів в Украӥні [Текст] / O.I. Шаповаленко, Т.I. Янюк // Проблемы развития современных комбикормовых технологий. Материалы научно-практической конференции с международным участием, посвященной 115-летию со дня рождения профессора Демидова П.Г. 26 - 27 июня 2008 г. - Одесса, 2008. - C. $16-22$.

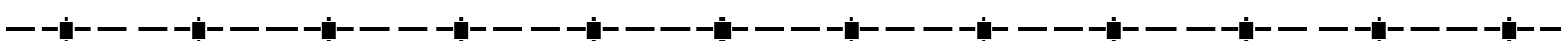

\section{O.I. KARUNSKIY ${ }^{1}$, Doctor of Agricultural Sciences, Professor, V.E. BRAZHENKO ${ }^{2}$, PhD. Sc. Science, Associate Professor, Ya.O. VELESIK ${ }^{2}$, holder of a master's degree, ${ }^{1}$ Odessa State Agrarian University, ${ }^{2}$ Odessa National Academy of Food Technologies}

\section{THE TECHNOLOGY OF PRODUCTION OF MIXED FODDERS, ENRICHED WITH LYSOZYME, FOR PIGS}

The characteristic of the immune system of a man's organism and functional purpose of ferments, have been determined. Nowadays one of the main directions of the man's immune system increase is production of safe products of vegetable and animal origin. Obtaining of high-quality production of animal origin depends on the genetic peculiarities of pigs' breeds, conditions of maintenance, programs of fattening at every stage of growing with providing of high quality fodders, which qualitative properties are influenced by introduction of innovation technologies of the production, the level of scientific working - out of mixed fodder production recipes with scientifically grounded application of enzyme preparations. The main biological effect of fodder enzymes has been determined. Application of the enzymes preparation of lysozyme in the composition of mixed fodder production in animal feeding, has been theoretically grounded. It has been established that introducing of the enzyme preparation lysozyme, into the composition of mixed fodder influences their efficient process increase.

The efficiency of introducing of the enzyme preparation of lysozyme, covered by gelatinous capsule, into the composition of mixed fodder production, has been theoretically and experimentally proved. The biologic efficiency of mixed fodder production, enriched by lysozyme and the efficient application of the enzyme preparation of lysozyme in the rats' diets, have been determined.

The composition of the mixed fodder recipe with application of "KormOptima" program has been calculated and optimum content of lysozyme concerning standards of feeding and indices of the nutritional value of the finished production for pigs, has been determined.

The technology of introduction of the lysozyme preparation has been developed and the experimental batch of mixed fodder for feeding the animals has been received. Scientific and economic experiments to study the efficiency of application of the enzyme preparation of lysozyme in the rations of pigs' feeding, have been carried out.

Zoological and technical efficiency of mixed fodder production, enriched by lysozyme, covered by gelatinous capsule, made according to the developed technology, for pigs, has been determined. It has been proved, that application of the lysozyme preparation in growing young pigs, allows to receive more efficiency and less expenditure of fodders by an item of production.

Key words: mixed fodder production, lysozyme preparation, the technology of the enzyme preparation introduction,efficiency.

\section{REFERENCES}

1. Yegorov, B.V. Technology of mixed fodders production [Text]: Textbook for student of higher educational institutions / B.V. Yegorov. - Odessa; Publishing House, 2011. - 448 p.

2. Yegorov, B.V. Experience of exploitation of mixed fodder plants of the $4^{\text {th }}$ generation [Text] / B.V. Yegorov, N.B. Vorona // Grain production and mixed fodders. - 2011. - № 4. - P. 24-29.

3. Levitskiy, A.P. Lysozyme instead of antibiotics [Text] / A.P. Levitskiy. - Odessa : KPOGT, 2005. - 74 c.

4. Yegorov, B.V. Technology of premixes production [Text]: Textbook / B.V. Yegorov, O.I. Shapovalenko, A.V. Makarinskaya K.: The Centre of educational literature, 2007. $-288 \mathrm{p}$.

5. Shapovalenko, O.I. The ways of development of mixed fodder production in Ukraine. [Text] / O.I. Shapovalenko, T.I. Yanyuk // Problems of development of the modern mixed fodder technologies. Materials of scientific and practical conference of the International level devoted to Professor P.G. Demidov's 115 - birthday 26 - 27 June 2008. - Odessa, 2008. - P. 16 - 22.

Надійшла 20.09.2014

Адреса для переписки: вул. Канатна, 112, м. Одеса, 65039

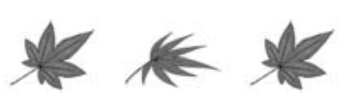

